Original Article

\title{
High Dilution of Dexamethasone in gestation and fetal development of mice
}

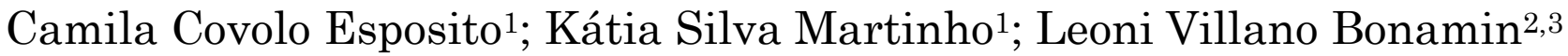

(1) Autonomous Veterinary Doctor, São Paulo, Brazil; (2) University Paulista, São Paulo, Brazil; (3) University of Santo Amaro, São Paulo, Brazil

\begin{abstract}
Background: Recently, the use of homeopathy in veterinary medicine has grown significantly, mainly for farm animal practice, because of its usefulness in organic production and low cost. There is a wide range of veterinary products available in the marketoften used in females. However, the effect of these products in the litter and derived products for human consummation is completely unknown. Aims: this study sought to develop an experimental model to study the putative effects of high diluted substances in newborns after chronic exposure of females. Methods: based on previous studies, the chosen test substance was dexamethasone $15 \mathrm{cH}$; adult female Balb/c mice were divided into 4 groups: a) treated with PBS (control); b) treated with dexamethasone $15 \mathrm{cH}$; c) treated with dexamethasone $15 \mathrm{cH}+$ dexamethasone $4 \mathrm{mg} / \mathrm{kg}$ and d) treated with dexamethasone $4 \mathrm{mg} / \mathrm{kg}$. All medicines were administered subcutaneously, 3 times a week, in females from the first day of pregnancy up to the 20th day after parturition (end of lactation period). TDevelopment of the offspring was evaluated daily for 15 days after birth. Parameters evaluated were: female and offspring viability, number of newborns, time for eye opening, pinna opening, fur growth and postural reflex. Results: the group treated with dexamethasone $15 \mathrm{cH}$ showed $39 \%$ increase in mortality rate 39 days after the beginning of treatment and $35 \%$ increase in fetal mortality at the end of gestation $(\mathrm{p}=0.0049)$. Females treated with dexamethasone $4 \mathrm{mg} / \mathrm{kg}$ + dexamethasone $15 \mathrm{cH}$ showed $100 \%$ of fetal mortality. After parturition newborn survival in animals exposed to dexamethasone $4 \mathrm{mg} / \mathrm{kg}$ was higher than the control ( $p=0.0002)$. All other parameters of neonatal development were unchanged among groups. Conclusions: these data point to adverse effect when using high diluted dexamethasone during gestation detectable by this experimental model in Balb/c mice.
\end{abstract}

Keywords: high dilution, homeopathy, neonatal, dexamethasone, toxicity.

\section{Introduction}

Recently, the use of homeopathy in veterinary medicine has grown significantly in some countries, mainly in farm animal practice, because of its usefulness in organic production and low cost [1-7]. There is a large range of veterinary products available in the current markets, which are often used in pregnant cows. However, the effect of these products in the litter and derived products for human consummation is poorly known.

Among the few studies available in the literature, Sommer et al. [8] tested different potencies of Sabina up to 30x to reduce placenta retention in cattle, in a study performed in 70 cows from 8 farms. The result was significant but increase in the incidence of mastitis and laminitis was also observed in treated groups. Recently, several studies about the use of homeopathic complexes as zootechnical tools in swine and chicken farms have been described [4-6].

On the other hand, it is classically known that corticoid hormones are critical agents of delivery outbreak and fetal development [9]. In previous studies, several effects of high diluted of dexamethasone have been 
described in different experimental models, including cell migration, proliferation and differentiation, inflammation and tumor development $[10,11]$.

In Bonamin et al. [10] and co-workers described the property of dexamethasone $7 \mathrm{cH}$ and $15 \mathrm{cH}$ (mathematically equivalent to $10^{-17} \mathrm{M}$ and $10^{-33} \mathrm{M}$ ) to modulate the acute inflammation induced by carrageenan and leukocyte migration to Ehrlich tumor site. In both cases, the simultaneous administration of high diluted dexametasone blocked the action of the same dexamethasone in pharmacological doses (Bonamin et al. [10]). In Martinho et al. [11] and collaborators described the effects of high diluted dexamethasone (7cH) to increase the pre-neoplastic lesions development in rat liver induced by carcinogenic substances (Martinho et al. [11]). These studies are in line with the recent trend to establish appropriate models to study the peculiar features of high dilutions biological effects, using single cell cultures, plants or animals [12-18].

The aim of this work was to propose an easy experimental model to study the putative effects of high diluted substances in newborns after mother chronic exposition.

\section{Material and methods}

\section{a. Animals}

Sixty days old female Balb/c mice were used in this experiment. They were maintained in conventional cages in a controlled environment, with artificial light cycle (12 hours light; 12 hours dark) and temperature fixed at $22 \pm 3^{\circ} \mathrm{C}$. Commercial food and potable water were offered ad libitum.

\section{b. Groups and treatment}

Group I - Control (PBS)

Group II - Dexamethasone $15 \mathrm{cH}$

Group III - Dexamethasone $15 \mathrm{cH}$ mixed with Dexamethasone $(4 \mathrm{mg} / \mathrm{kg})$ in the same shot

Group IV - Dexamethasone $(4 \mathrm{mg} / \mathrm{Kg})$

Treatments were done three times a week, subcutaneously, in a volume equal to $0.1 \mathrm{ml} / 10 \mathrm{~g}$ of weight, during all gestational (21 days) and lactation (20 days) period. Each group was composed by 15 female and 15 male mice. Male mice were used only for procreation.

\section{c. Drugs}

PBS - Phosphate buffer saline (SIGMA) prepared in distilled water. It was used as negative control.

Dexamethasone $15 \mathbf{c H}$ - The centesimal dilutions of Decadron ${ }^{\circledR}$ were prepared in a serial manner in distilled water up to $14 \mathrm{cH}$. The last dilution $(15 \mathrm{cH})$ was made in PBS, observing the same proportions. The final solution reached the concentration mathematically equal to $10^{-33}$ moles/liter. All dilutions were succussed according to the classical Hahnemannean method.

Dexamethasone $4 \mathrm{mg} / \mathrm{kg}$ - The commercial form of dexamethasone (Decadron ${ }^{\circledR}$ ) was diluted in PBS without succussion in order to reach the dose of $4.0 \mathrm{mg} / \mathrm{kg}$.

Mixed Dexamethasone $15 \mathrm{cH}$ and $4 \mathrm{mg} / \mathrm{kg}$ - The commercial form of dexamethasone (Decadron ${ }^{\circledR}$ ) was diluted in the homeopathic form dexamethasone $15 \mathrm{cH}$ in order to reach the dose of $4.0 \mathrm{mg} / \mathrm{kg}$. 
The potency $15 \mathrm{cH}$ was chosen because, although beyond the Avogadro's number, is low enough to interfere in acute-physical parameters, according to its traditional homeopathic clinical use. Also, previous data related to the effects of dexamethasone $15 \mathrm{cH}$ in inflammatory process were already related by us previously (Bonamin et al. [10]). The fact to be beyond Avogadro's number excludes completely the possibility of any molecular transmission between mother and fetuses via placenta, which could result in false positive results.

\section{d. Control of treatment period}

Day zero of pregnancy: Was determined as the first day in which females were put together with males. This procedure lasted up to one week for all tested females.

Final of treatment: weaning, twenty days after parturition.

\section{e. Post-natal evolution}

After parturition, the number of days corresponding to the pregnancy period and the number of viable newborns were registered.

From the day of birth, the following parameters would be also registered:

1. day of fur appearance

2. day of pinna opening

3. day of testicle dehiscence

4. day of complete development of postural reflex

The postural reflex is evaluated by the capacity of newborn to recover immediately the quadruped position after be lay in dorsal decubitus.

After weaning, females were sacrificed and the number of implantations was registered.

\section{f. Statistical analysis}

For evaluation of all newborn parameters, including mother mortality, the Fisher test was used, being $\mathrm{p} \leq 0.05$. This test was done using the Graph Pad Instat for Windows software. The Fisher test was chosen because it is the most adequate test to compare proportions between groups within little samples.

\section{Results}

\section{a. Mortality}

A clear trend of dexamethasone $15 \mathrm{cH}$ to increase mother mortality in relation to control (39\%) was observed between days zero and 30, although without statistical significance (Figure 1). After death, these animals were necropsied and general fetal death was observed. 


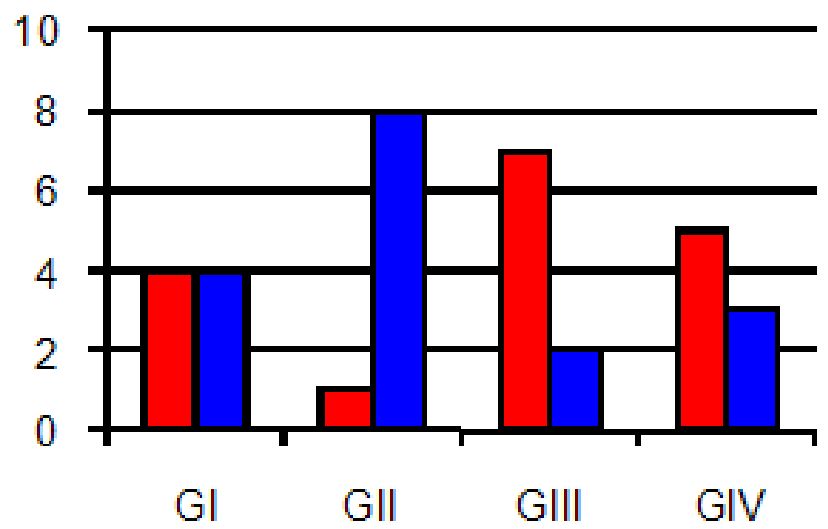

Figure 1 - Proportion of live (red column) and dead (blue column) female in the first 30 days of the experiment. $\mathrm{Y}$ axis $=$ number of pregnant females; GI = control; GII = dexamethasone $15 \mathrm{CH} ;$ GIII = dexamethasone $(4 \mathrm{mg} / \mathrm{kg})+$ dexamethasone $15 \mathrm{CH}$; GIV = dexamethasone $4 \mathrm{mg} / \mathrm{kg}$. Fisher's test.

\section{b. Pregnancy and cannibalism}

There was no statistical significance between groups regarding to pregnancy duration. The group treated with both, dexamethasone $15 \mathrm{cH}$ and dexamethasone $4 \mathrm{mg} / \mathrm{kg}$ at the same time, presented $100 \%$ of newborn mortality. In the other groups there was no mortality, but cannibalism was detected (Table 1).

Table 1. Mother parameters during perinatal period.

\begin{tabular}{lcccc}
\hline & control & $\begin{array}{l}\text { Dexamethasone } \\
\mathbf{1 5 c H}\end{array}$ & $\begin{array}{l}\text { Dexamethasone } \\
\mathbf{1 5 c H}+\mathbf{4 m g} / \mathbf{k g}\end{array}$ & $\begin{array}{l}\text { Dexamethasone } \\
\mathbf{4 m g} / \mathbf{k g}\end{array}$ \\
\hline $\begin{array}{l}\text { Pregnancy } \\
\text { duration (days)* }\end{array}$ & 22 & 24 & $\#$ & 23 \\
& & & & yes \\
\hline
\end{tabular}

\# 100\% of precocious fetal mortality; Fisher's test.

\section{c. Newborn evolution parameters}

Since cannibalism was observed, the later parameters, such as the day of testicle dehiscence and the day of complete development of postural reflex could not be registered. In relation to fur appearance and pinna opening, no statistically significance was observed (Table 2).

Table 2. Newborn development. The data represent the median of days needed to observation of each parameter.

\begin{tabular}{|c|c|c|c|}
\hline & Control & $\begin{array}{l}\text { Dexamethasone } \\
15 \mathrm{cH}\end{array}$ & $\begin{array}{l}\text { Dexamethasone } \\
4 \mathrm{mg} / \mathrm{kg}\end{array}$ \\
\hline Fur appearance (days) & 2 & 2 & 2 \\
\hline Pinna opening (days) & 2 & 2 & 2 \\
\hline
\end{tabular}

Fisher's test. 
The third group was not represented because all newborns were dead.

\section{d. Number of newborn}

The number of newborns at the end of pregnancy in dexamethasone $15 \mathrm{cH}$ treated group was superior to the other groups, although without statistical significance. However, the ratio number of newborns/number of fetuses at the final stage of pregnancy was $35 \%$ smaller than the control group ( $p=0.0047)$. No implantations were seen in mice treated with dexamethasone $15 \mathrm{cH}$ and dexamethasone $4 \mathrm{mg} / \mathrm{kg}$ at the same time. The group treated with dexamethasone $4 \mathrm{mg} / \mathrm{kg}$ alone presented the ratio equal to 1 ( $\mathrm{p}=0.0002)$ (Table 3 ).

Table 3. Number of newborns / number of fetuses' ratio among groups.

\begin{tabular}{|c|c|c|c|c|}
\hline & control & $\begin{array}{l}\text { Dexamethasone } \\
15 \mathrm{cH}\end{array}$ & $\begin{array}{l}\text { Dexamethasone } \\
15 \mathrm{cH}+4 \mathrm{mg} / \mathrm{kg}\end{array}$ & $\begin{array}{l}\text { Dexamethasone } \\
4 \mathrm{mg} / \mathrm{kg}\end{array}$ \\
\hline Total of fetuses & 13 & 33 & 0 & 7 \\
\hline $\begin{array}{l}\text { Total of } \\
\text { newborns }\end{array}$ & 5 & 1 & 0 & 7 \\
\hline $\begin{array}{l}\text { Newborns/fetuses } \\
\text { ratio }\end{array}$ & 0.38 & $0.03^{*}$ & 0 & $1 \#$ \\
\hline
\end{tabular}

* Fisher test, $\mathrm{p}=0.0049$; \# Fisher test, $\mathrm{p}=0.0002$ in relation to control

\section{Discussion}

The deleterious effect of corticoid during gestation is well known. This toxic effect is related to the role of this hormone in the early parturition induction. Physiologically, during delivery, the release of corticosterone by mice fetal adrenals induces inversion of progesterone/oestrogenous ratio in mother serum. These changes in endocrine panel result in prostaglandin secretion by endometrial cells and oxytocin release by posterior pituitary, followed by the expulsion of fetuses [19]. In the veterinary practice, the use of corticoid to synchronize parturitions in farm animals was already mentioned, although placenta retention can occur in some cases [20].

In this study, several interesting findings about high dilutions of dexamethasone were observed. Female treated with dexamethasone $15 \mathrm{cH}$ during pregnancy suffered higher percentage of mortality than the control, with associated fetuses' death. The dexamethasone $15 \mathrm{cH}$ seems to potentiate the toxic effect of dexamethasone $4 \mathrm{mg} / \mathrm{kg}$ regarding fetal absorption. The exposition of mothers to dexametasone $15 \mathrm{cH}$ during gestation resulted in significant decrease of newborn viability; the association of dexamethasone $4 \mathrm{mg} / \mathrm{kg}$ with high diluted dexamethasone potentiated this toxic effect, since no implantations were observed in this group. These results suggest some kind of "antagonism" of high diluted dexamethasone regarding the endogenous cycle of corticosterone in pregnant mice, although more experiments have to be done to confirm the data and explain their mechanisms. to explain their mechanism. Additional studies using other mouse strain or species (such as rats) would be useful to identify the general impact of high diluted dexamethasone in pregnancy, since Balb/c mice is too much sensitive to stress during gestation. Thus, the exacerbated results observed here could be related to it. This hypothesis is sustained by previous results obtained by our group demonstrating the interference of high diluted dexamethasone in other physiopathological situations $[10,11]$.

Several data about the effects of high dilutions of endogenous substances on fetal development have been described in the last 15 years. Youbicier-Simo et al. [21] observed that in ovo treatment of bursectomized 
chicken embryos with high diluted Bursin is able to recover B lymphocyte function - that was lost by bursectomy - and also all endocrine functions related to it, such as melatonine, ACTH and corticoid serum levels. One of the most studied models about the effect of high dilution of hormones in differentiation process is that created by PC Endler and co-workers. In multi-centric studies, they demonstrated that high dilutions of thyroxin modulate the metamorphosis rate of Rana temporaria [22, 23]. These results were also reproduced in different environmental conditions by Guedes et al. [24].

The use of homeopathic products in farm animals has been increased in the last years [1-7, 25], but few studies about the influence of these products in pregnancy and offspring are reported. In 2006, Rajkumar et al. [26] demonstrated that the treatment of cows with a complex composed by Calcarea phosphorica 30c, Sepia 30c and Phosphorus 30c in equal proportions increased oestradiol plasma concentration and was effective in inducing oestrus in anoestrus animals but no information is provided about fetal development and pregancy. In human clinical practice, the lack of information regarding this approach is also noticed. In 2006, a case report about induction of labor using Caulophyllum thalictroides and Cimicifuga racemosa 30c in a 28 years old woman was published. The effects in fetal development were neither described (Kistin et al., [27]).

Recently, a large review about animal experimental models to study high dilutions was published (Bonamin; Endler, [14]), but no pregnancy model was found in the literature. Herein, the proposed model was sensible enough to identify putative effects of high dilutions of endogenous substances in pregnancy and fetal development, indicating it could be a good tool for the characterization of this particular aspect of homeopathy biological activity. The implications of the use of homeopathic medicines according to the strict similia principle in pregnant females still remain unsolved.

\section{References}

[1] Barbour EK, Sagherian V, Talhouk S, Talhouk R, Farran MT, Sleiman FT, Harakeh S. Evaluation of homeopathy in broiler chickens exposed to live viral vaccines and administered Calendula officinalis extract. Med Sci Monit. 2004; 10: 281-285.

[2] Varshney JP, Naresh R. Evaluation of a homeopathic complex in the clinical management of udder diseases of riverine buffaloes. Homeopathy. 2003; 93: 17-20.

[3] Barzon CD, Medeiros F, Moraes RE, Silva LCM, Massambani C, Takemura OS, Gazim ZC. Preliminary study of homeopathic treatment of subclinical mastitis evaluated through somatic cells count and California mastitis test. Int J High Dilution Res [online]. 2008 [cited 2009 Dec 14]; 7(24): 147-151. Available from: http://www.feg.unesp.br/ ojs/index.php/ijhdr/article/view/292/364.

[4] Soto F, Vuaden E, Coelho C, Benites N, Bonamin LV, De Azevedo S. A randomized controlled trial of homeopathic treatment of weaned piglets in a commercial swine herd. Homeopathy. 2008; 97: 202-205.

[5] Soto FRM, Vuaden ER, Coelho CP, Bonamin LV, Azevedo SS, Benites NR. Uso de Medicação Homeopática para Redução da Mortalidade em Leitões por Doenças Infecciosas na Fase de Creche em uma Granja Comercial de Suínos. Vet Zootec. 2008; 15: 332-339.

[6] Soto FRM, Vuaden ER, Coelho CP, Bonamin LV, Azevedo SS, Benites NR. Efeito da Avena sativa CH6 no metabolismo do sêmen diluído de suínos. Vet Zootec. 2009; 16(2): 367-372.

[7] Amalcaburio R, Machado Filho LCP, Honorato LA, Menezes NA. Homeopathic remedies in a semiintensive alternative system of broiler production. Int J High Dilution Res [online]. 2009 [cited 2009 Dec 14]; 8 (26): 33-39. Available from: http://www.feg.unesp.br/ ojs/index.php/ijhdr/article/view/325/383. 
[8] Sommer H, Erber U, Wirth E. The efficiency preventive homeopathic treatment of postparturient diseases of dairy cattle. Proceedings of the: IV International Congress of the International Society for Animal Clinical Biochemistry; 1990 Jul 18-21; Davis, United States. p 143-150.

[9] Moiser HD, Dearden LC, Roberts RC, Jansons RA, Biggs CS. Regional differences in the effects of glucocorticoids on maturation of the fetal skeleton of the rat. Teratology. 1981; 23: 15-24.

[10] Bonamin LV, Martinho KS, Nina AL, Caviglia F, Do Rio RGW. Very high dilutions of dexamethasone inhibit its pharmacological effects in vivo. British Homeopathic Journal. 2001; 90: 198-203.

[11] Martinho KS, Bento VB, Benvenga GU, Marcondes VA, Bonamin LV. Hepatic cell growth models for the study of ultra high dilutions. In: Bonamin LV editor. Signal and Images: contributions and contradictions about high dilution research. Dordrecht: Springer; 2008. 83-96.

[12] Bellavite P, Magnani P, Marzotto M, Conforti A. Assays of homeopathic remedies in rodent behavioural and phychopathological models. Homeopathy. 2009; 98: 208-227.

[13] Betti L, Trebbi G, Majewsky V, Scherr C, Shah-Rossi D, Jäger T, Baumgartner S. Use of homeopathic preparations in phytopathological models and in field trials: a critical review. Homeopathy. 2009; 98: 244-266.

[14] Bonamin LV, Endler PC. Animal models for studying homeopathy and high dilutions: conceptual critical review. Homeopathy. 2009; 99: 1-14.

[15] Khuda-Bukhsh AR. Mice as a model for homeopathy research. Homeopathy. 2009; 98:267-279.

[16] Majewsky V, Arlt S, Shah D, Scherr C, Jäger T, Betti L, Trebbi G, Bonamin LV, Klocke P, Baumgartner S. Use of homeopathic preparations in experimental studies with healthy plants. Homeopathy. 2009; 98: 228 243.

[17] Sainte-Laudy J; Belon P. Inhibition of basophil activation by histamine: a sensitive and reproducible model for the study of the biological activity of high dilutions. Homeopathy. 2009; 98: 186-197.

[18] Van Wijk R, Clausen J, Albrecht H. The rat in basic therapeutic research in homeopathy. Homeopathy. 2009; 98: 280-286.

[19] Toniollo HG, Russiono RW. Manual de Obstetrícia Veterinária. São Paulo: Varela; 1995.

[20] Booth HN, Mac Donald LE. Farmacologia e Terapêutica em Veterinária. Rio de Janeiro: Guanabara Koogan; 1992.

[21] Youbicier-Simo BJ, Boudard F, Guellati M, Mekaouche M, Baylé JD, Bastide M. The role of the Bursa de Fabricius and highly dilute bursin in immunoendocrine interactions in the chickens. In: Bastide M editor. Signal and Images. Dordrecht: Kluwer; 1997. 121-148.

[22] Endler PC, Lüdtke R, Heckmann C, Zausner C, Lassnig H, Scherer-Pongratz W, Haidvogl M, Frass M. Pretreatment with thyroxine (10-8 parts by weight) enhances a curative effect of homeopathically prepared thyroxine (10-13) on lowland frogs. Forsch Komplementärmedizin Klass Naturheilkd. 2003; 10: 137-142.

[23] Welles SU, Endler PC, Scherer-Pongratz W, Suanjak-Traidl E, Weber S, Spranger H, Frass M, Lothaller H. Pretreatment with thyroxin 10e-8 and the effect of homeopathically prepared thyroxin 10-30 on highland frogs - a multi researcher study. Forsch Komplementärmedizin Klass Naturheilkd. 2007; 14: 353-357. 
[24] Guedes JRP, Ferreira CM, Guimarães HMB, Saldiva PHN, Capelozzi VL. Homeopathically prepared dilution of Rana catesbeiana thyroid glands modifies its rate of metamorphosis. Homeopathy. 2004; 93: 132137.

[25] Souza ACM, Vuaden ER, Coelho CP, Bonamin LV, Azevedo SS, Benites NR, Vasconcellos AS, Soto FRM. Influência do tratamento Homeopático de fêmeas suínas no dedempenho zootécnico de suas proles submetidas ao manejo de ressecção de dentes e a amputação do terço distal da cauda. Vet Zootec. 2009; 16(3): 471-477.

[26] Rajkhumar R, Srivastava SK, Yadav MC, Varshney VP, Varshney JP, Kumar H. Effect of a homeopathic complex on oestrus induction and hormonal profile in anoestrus cows. Homeopathy. 2006; 95:131-135.

[27] Kistin SJ, Newman AD. Induction of labor with homeopathy: a case report. J Midwifery Womens Health. 2007; 52(3): 303-307.

\title{
Efeitos de altas diluições de dexametasona na gestação e no desenvolvimento fetal de camundongos
}

\begin{abstract}
RESUMO
Justificativa: a utilização da homeopatia na medicina veterinária tem crescido significativamente devido a questões relacionadas à produção orgânica e ao baixo custo. Atualmente há uma grande oferta de medicamentos homeopáticos para animais de criação, sobretudo em fase de gestação e lactação, mas pouco se sabe sobre as consequências desta exposição para a cria ou nos produtos derivados para consumo humano. Objetivos: este trabalho visa o desenvolvimento de um modelo experimental para estudar os efeitos da exposição crônica das fêmeas a substâncias altamente diluídas nos recém-nascidos. Métodos: com base em estudos anteriores, a substância escolhida foi dexametasona $15 \mathrm{cH}$; camundongas adultas Balb/c foram divididas em 4 grupos: a) tratado com PBS (controle), b) tratado com dexametasona $15 \mathrm{cH}$; c) tratado com dexametasona $15 \mathrm{cH}+$ dexametasona $4 \mathrm{mg} / \mathrm{kg}$; e d) tratado com dexametasona 4 $\mathrm{mg} / \mathrm{kg}$. Todos os medicamentos foram administrados por via subcutânea, 3 vezes por semana, nas fêmeas, a partir do primeiro dia de gravidez até o dia 20 após o parto (final do período de lactação). O desenvolvimento da prole foi avaliado diariamente durante 15 dias após o nascimento. Os parâmetros avaliados foram: viabilidade das fêmeas e crias, número de recémnascidos, tempo para a abertura dos olhos, descolamento de orelha, crescimento do pelame e reflexo postural. Resultados: faz fêmeas tratadas com dexametasona $15 \mathrm{cH}$ apresentaram $39 \%$ de aumento no índice de mortalidade após 39 dias do início do tratamento e um aumento de 35\% na mortalidade fetal no final da gestação $(p=0,0049)$. Fêmeas tratadas com dexametasona $4 \mathrm{mg} / \mathrm{kg}+$ dexametasona $15 \mathrm{cH}$ apresentaram $100 \%$ de mortalidade fetal. Após o parto, a sobrevivência dos animais recém-nascidos expostos a dexametasona $4 \mathrm{mg} / \mathrm{kg}$ foi melhor do que o controle $(\mathrm{p}=0,0002)$. Todos os outros parâmetros de desenvolvimento neonatal não foram alterados, entre os grupos. Conclusões: os dados apontam para a existência de efeitos adversos da dexametasona altamente diluída durante a gestação, detectáveis por este modelo experimental em camundongos Balb/c.
\end{abstract}

Palavras-chave: altas diluições, gestação, neonatos, dexametasona, toxicidade, ratos.

\section{Efectos de las altas diluciones de dexametasona durante la gestación y el} desarrollo fetal de ratones 


\section{RESUMO}

Justificación: el uso de la homeopatía en la medicina veterinaria ha crecido considerablemente debido a cuestiones relacionadas con la producción agroecológica y el bajo costo. Actualmente hay una amplia gama de medicamentos homeopáticos para animales de granja, especialmente en el proceso de gestación y la lactancia, pero poco se sabe sobre las consecuencias de esta exposición en las crías o en los productos para consumo humano. Objetivos: este trabajo tiene como objetivo desarrollar un modelo experimental para estudiar los efectos de la exposición crónica de las hembras a sustancias altamente diluidas en los recién nacidos. Métodos: sobre la base de estudios anteriores, la sustancia elegida fue dexametasona $15 \mathrm{cH}$; ; atones adultos hembra Balb/c fueron divididos en 4 grupos: a) tratado con PBS (control); b) tratado con dexametasona $15 \mathrm{cH}$; c) tratado con dexametasona $15 \mathrm{cH}$ + dexametasona $4 \mathrm{mg} / \mathrm{kg}$; y d) tratado con dexametasona 4 $\mathrm{mg} / \mathrm{kg}$. Todos los fármacos fueron administrados por vía subcutánea 3 veces por semana en las hembras desde los primeros días del embarazo hasta 20 días después del parto (final de la lactancia). El desarrollo de las crías fue evaluado durante 15 días después del nacimiento. Los parámetros evaluados fueron: viabilidad de hembras y fetos, número de recién nacidos, tiempo para abrir los ojos, separación de las orejas, crecimiento del pelo y reflejos posturales. Resultados: las hembras tratadas con dexametasona $15 \mathrm{cH}$ presentaron un incremento del $39 \%$ en la tasa de mortalidad después de 39 días de iniciado el tratamiento y un aumento del $35 \%$ en la mortalidad fetal tardía en el embarazo $(p=0,0049)$. Hembras tratadas con dexametasona 4 $\mathrm{mg} / \mathrm{kg}+$ dexametasona $15 \mathrm{cH}$ presentaron $100 \%$ de mortalidad fetal. Después del parto, la supervivencia de los animales recién nacidos expuestos a dexametasona $4 \mathrm{mg} / \mathrm{kg}$ fue mejor que el control $(p=0,0002)$. Todos los demás parámetros de desarrollo neonatal no cambiaron entre los grupos. Conclusiones: estos datos indican la existencia de efectos adversos de la dexametasona altamente diluida durante la gestación, detectables mediante este modelo experimental en ratones Balb/c.

Palabras clave: altas diluciones, gestación, neonatos, dexametasona, toxicidad, ratones.

\section{(c)) BY-NC-ND Licensed to GIRI}

Support: authors declare that this study received no funding

Conflict of interest: authors declare there is no conflict of interest

Received: 30 November 2009; Revised: 07 December 2009; Published: 17 December 2009.

Correspondence author: Leoni Villano Bonamin, leonibonamin@unip.br.

How to cite this article: Esposito CC, Martinho KS, Bonamin LV. High Dilution of dexamethasone in gestation and fetal development of mice. Int J High Dilution Res. 2009 [cited YYYY Month dd]; 8 (29): 146-154. Available from: http://www.feg.unesp.br/ ojs/index.php/ijhdr/article/view/366/406. 